\title{
1. Territorial conflicts and their international legal framework
}

\author{
Marcelo G. Kohen and Mamadou Hébié
}

\section{THE MEANING AND SCOPE OF TERRITORIAL CONFLICTS}

The notion of 'territorial conflict' may embrace various kinds of disagreements. In its broad sense, it includes all types of disputes relating to territory. In this meaning, disputes as to ownership as well as to use of territory can be included in the notion of 'territorial conflict'. The latter includes potential trans-boundary environmental harm. For example, conflicts arising from the extraterritorial exercise of state competencies in foreign land could also be included within this large definition. Territorial conflicts occur because the world is essentially divided into states exercising their sovereignty over a given portion of it. The spatial division of the Earth into different areas and with different legal statuses is the product of human activity throughout history. Some of these areas are subject to the appropriation by states, but others, such as the high seas, are not. For the former, states may have sovereignty over them, although other legal regimes have also been applicable. The area in which sovereignty exists or may exist is essentially land and is generally referred to as 'territory'. As will be discussed later, the legal meaning of 'territory' includes other areas besides land. Disputes as to control over, or use of spaces may also refer to areas other than land, such as maritime areas, the airspace or the outer space. Conflicts may assume a variety of forms, the more extreme of them is war or, to use the precise current terminology, armed conflicts. Territorial change or control thereof has indeed been the source of most international conflicts in history. Conflicts may be the result of a divergence of views on the legal situation with regard to a given territory or the attempt by one of the parties to change the existing legal situation, hence the need to circumscribe clearly the scope of this Research Handbook. The following sections consequently propose definitional elements of the key notions: conflicts, territory and sovereignty.

\section{A. Conflicts and Disputes}

In general, the terms 'conflicts' and 'disputes' are used indistinctively. As a matter of fact, even if the two concepts are intertwined, they are not synonyms. In his Agenda for Peace, the former United Nations (UN) Secretary-General Boutros Boutros-Ghali, while discussing preventive diplomacy, mentioned as one of its meanings the action 'to prevent existing disputes to escalate into conflicts'. ${ }^{1}$ Disputes may essentially refer to

1 U.N. Secretary-General, An Agenda for Peace: Preventive Diplomacy, Peacemaking and Peacekeeping, Rep. of the Secretary-General pursuant to the statement adopted by the Summit Meeting of the Security Council on 31 January 1992, 45, U.N. Doc A/47/277 (June 17, 1992). 


\section{Research handbook on territorial disputes in international law}

the content of the question that opposes two or more actors, whereas conflicts refer to specific situations that involve tensions, coercive measures of different kinds, including threats or use of force. This Research Handbook will focus on the content of territorial conflicts and not on the fallouts arising from their existence in the bilateral relations of their actors or at the multilateral level. In other words, it is territorial disputes as such that are at issue here.

The existence of a dispute is relevant for different reasons. In particular, only if a dispute really exists can the International Court of Justice or an arbitral tribunal exercise its jurisdiction. ${ }^{2}$ In practice, it happens that a party to a dispute may invoke its inexistence. This is the reason why both the Permanent Court of International Justice and the International Court of Justice have extensively discussed the content of this notion and delineated its contours. The Permanent Court's definition given in the Mavrommatis case has constantly been cited as the starting point in this field. According to the Court, a dispute is 'a disagreement on a point of law or fact, a conflict of legal views or of interests between two persons' ${ }^{3}$ The International Court of Justice better explained this notion, among others, in the South West Africa (Ethiopia v. South Africa; Liberia v. South Africa) cases. A mere conflict of interests does not necessarily imply the existence of a dispute. To determine whether a dispute exists:

[It] is not sufficient for one party to a contentious case to assert that a dispute exists with the other party. A mere assertion is not sufficient to prove the existence of a dispute any more than a mere denial of the existence of the dispute proves its nonexistence. Nor is it adequate to show that the interests of the two parties to such a case are in conflict. It must be shown that the claim of one party is positively opposed by the other. ${ }^{4}$

The manner in which this positive opposition of claims is manifested varies from case to case. Normally, this appears to be the case when one party lodges a protest against acts or claims made by the other. In territorial disputes, the positive opposition of claims between the parties generally occurs when one side asserts its sovereignty and

2 In the Frontier Dispute (Burkina Faso/Niger) case, the parties submitted a boundary dispute to the Court while at the same time requested it to place on record their agreement with respect to two sectors of their boundary. Invoking Article 38 of the Statute of the International Court of Justice, the Court clarified that its 'function is to decide in accordance with international law such disputes as are submitted to it', the Court considered that this joint request of the parties was 'not compatible with its judicial function'. See Frontier Dispute (Benin/Niger), Judgment, I.C.J. 90, 72, para. 58 (12 July). See also Case concerning the Northern Cameroons (Cam v. U. K.), Preliminary Objections, Judgment, 1963 I.C. J. 15, 27 and 33-4 (2 December).

3 Mavrommatis Palestine Concessions (Greece v. U.K.), Judgment 1924 P.C.I.J. (ser. B) No. 2, at 11 (30 August).

4 South West Africa (Eth. v. S. Afr.; Liber. v. S. Afr.), Preliminary Objections, 1962 I.C.J. 319, 328 (21 December). The Court had previously stated 'whether there exists an international dispute is a matter for objective determination. The mere denial of the existence of a dispute does not prove its non-existence'. See Interpretation of Peace Treaties with Bulgaria, Hungary and Romania, Advisory Opinion, 1950 I.C.J. 65, 74 (30 March). 
the other side protests for the first time, or when the first protest by one state is rejected by the other. ${ }^{5}$ However, as the Court indicated:

[T] he positive opposition of the claim of one party by the other need not necessarily be stated expressis verbis. In the determination of the existence of a dispute, as in other matters, the position or the attitude of a party can be established by inference, whatever the professed view of that party. ${ }^{6}$

In the Obligations concerning Negotiations relating to Cessation of the Nuclear Arms Race and to Nuclear Disarmament (Marshall Islands v. United Kingdom) case, the Court raised the threshold of the factual elements necessary for the existence of a dispute to the situation "when it is demonstrated, on the basis of the evidence, that the respondent was aware, or could not have been unaware, that its views were "positively opposed" by the applicant'.

It may be that in a given territorial dispute, one of the parties denies the existence of the dispute or, which is the same, considers that the dispute has been already settled. This 'dispute about the existence of a dispute' was discussed before the Court in $E l$ Salvador/Honduras and in Territorial and Maritime Dispute (Nicaragua v. Colombia). In the El Salvador/Honduras case, the former state advanced a claim over the island El Tigre but Honduras considered that there was none. The Chamber of the International Court of Justice was of the view that in order to decide, it had to take into account that 'the existence of a dispute over an island can, in the present proceedings, be deduced from the fact of its being the subject of specific and argued claims' ${ }^{8}$ In doing so, the Chamber observed that 'the existence of a dispute does not depend on the objective validity of the claims of the Parties to it'. ${ }^{9}$ The Chamber decided that a dispute as to the sovereignty over El Tigre existed and that the territory belonged to Honduras.

In Nicaragua $v$. Colombia, the question at stake was whether a dispute still existed between the two countries with regard to the islands of San Andrés, Providencia and Santa Catalina of the San Andrés Archipelago in the Caribbean Sea. By a treaty of 1928, Nicaragua had expressly recognized Colombian sovereignty over them, although it declared this treaty null and void in 1980 or considered later that at least it was terminated. The Court disregarded the nullity of the treaty and considered that even if the treaty had been terminated, Colombian sovereignty would have been maintained, as a boundary established by a treaty has an independent legal existence from this legal

5 Sovereignty over Pedra Branca/Pulau Batu Puteh, Middle Rocks and South Ledge (Malay./Sing), Judgment, 2008 I.C.J. 12, 28, para. 33 (23 May) (observing that ' $[\mathrm{t}]$ he Parties are agreed that, with regard to Pedra Branca/Pulau Batu Puteh, the dispute crystallized in 1980, when Singapore and Malaysia formally opposed each other's claims to the island').

6 Land and Maritime Boundary between Cameroon and Nigeria (Cameroon v. Nigeria: Eq. Guinea intervening), Preliminary Objections, 1998 I.C.J. 275, 315, para. 89 (11 June).

7 Obligations concerning Negotiations relating to Cessation of the Nuclear Arms Race and to Nuclear Disarmament (Marsh. Is. v. U.K.), Preliminary Objections, 2016 I.C.J. 1, 18, para. 41 (5 October).

8 Land, Island and Maritime Frontier Dispute (El Sal./Hond.: Nicar. intervening), Judgment, 1992, I.C.J. 351, 555, para. 326 (11 September).

9 Id., at 556, para. 329. 


\section{Research handbook on territorial disputes in international law}

instrument. Consequently, the Court held that there was no 'legal dispute' between the parties about these three islands. ${ }^{10}$

States parties to territorial disputes may adopt different measures to manage their disputes. The existence of an agreement relating to the management of the dispute does not imply its inexistence. The treaty governing Antarctica - although it concerns a territory whose status is also the object of different positions - is the most well-known example of treaties freezing the claims of the parties to the dispute. ${ }^{11}$ Other dispute management measures include joint venture agreements whereby the parties create a framework to exploit the natural resources of the disputed territory, without prejudice to their respective claims, or organize its administration pending the settlement of the dispute. ${ }^{12}$ However, these questions fall beyond the scope of this work.

In this Research Handbook, what will be addressed are territorial disputes and their legal treatment as to their content. As will be seen, territorial disputes imply the existence of competing argued claims. Arguments may be of different natures, as will be addressed in the following section.

\section{B. Legal and Political Disputes}

A distinction can be made between legal and political disputes. This does not mean that a single dispute cannot include both political and legal elements. As the Court observed, 'disputes between sovereign States by their very nature are likely to occur in political contexts, and often form only one element in a wider and longstanding political dispute between the States concerned.' ${ }^{13}$ In territorial disputes, the political character may be present at the origin of the claim and may continue through the management of the dispute by the parties. The distinction can be traced through the nature of the claims concerned. A claim based on legal arguments arguing that the territory in question belongs to the state concerned that is opposed by the other party also invoking legal grounds to claim its own sovereignty over the same territory is a legal dispute. A claim advanced by a state that recognizes that a territory is currently under the sovereignty of another state but for reasons of convenience (which can be economic, geographic, ethnic or whatever other nature) should pass to it, is a mere political one, namely, not based in existing and applicable international legal rules. A typical example of the latter is Nazi Germany's claim over the Sudeten, a Czechoslovakian territory.

As Sir Robert Jennings explained, '[a] 'legal dispute' in a technical and realistic sense is accordingly one which has been thus processed, or reduced, into a form

10 Territorial and Maritime Dispute (Nicar. v. Colom.), Preliminary Objections, 2007 I.C.J. 832, 861 and 873-4, paras. 88-90 and 138 (13 December).

11 See arts. 1, 4 and 5 of the Antarctic Treaty, June 23, 1961, 402 U.N.T.S. 71.

12 A good example is the agreement of 7 September 2009 between Benin and Burkina Faso, by which the parties agreed that the disputed area of Kourou/Koalou will be administered by a Joint Management Committee and that no unilateral action could be asserted by any party in the disputed area, pending the settlement of the dispute.

13 United States Diplomatic and Consular Staff in Tehran (U.S. v. Iran), Judgment, 1980 I.C.J. 3, 20, para. 37 (24 May). 
suitable for decision by a court of law: i.e. a series of specific issues for decision' ${ }^{14}$ In this regard, non-legal claims do not prosper before international courts or tribunals, which, in general, are entrusted with the task to decide territorial disputes based on international law. ${ }^{15}$ Thus, in Croatia/Slovenia, among the consequences that the arbitral tribunal attached to the terms of its mandate under the arbitration agreement, the tribunal listed that:

First, it defines the powers and duties of the Tribunal. The Tribunal has neither the right nor the legal power to decide upon the course of the boundary except by applying the rules and principles of international law. Factors that are legally irrelevant, or which the Parties have expressly decided should be excluded from consideration, must not be taken into account by the Tribunal in reaching its decision. The Tribunal is required to decide the matter from the legal, and not from the historical or political or sociological perspective. That is what the two Governments have chosen and mandated. ${ }^{16}$

This Research Handbook will only address legal territorial disputes.

\section{Territorial Disputes and Boundary Disputes}

The territory is essentially constituted by land, but not exclusively. All emerged land is territory and then capable of being subjected to the sovereignty of a state. This includes islands, which are subject to a classification leading to different rules as to their sovereignty, as discussed below. Elements other than emerged land also form part of the legal notion of territory. Waterways (such as rivers, lakes, aquifers) and some specific maritime areas, such as internal and historical waters, the territorial sea and the archipelagic waters, are under the legal regime of sovereignty. Subsoil of both land and these maritime areas is also included within the territory of the state. In other maritime areas, such as the continental shelf or the economic exclusive zone, riparian states only have specific 'sovereign rights' ${ }^{17}$ Under Article 11 of the UN Convention on the Law of the Sea (hereinafter UNCLOS), a state's title to a territorial sea is a legal corollary of the possession of maritime coasts. The same applies to other maritime areas under state jurisdiction. Under Article 3 of the UNCLOS, the breadth of the territorial sea extends to twelve nautical miles from the baseline. As far as its delimitation between opposite

14 Robert Jennings, Reflections on the Term 'Dispute' in EsSAYS IN HoNOUR OF WANG TIEYA 401, 403 (Ronald MacDonald ed., 1993). Defining the legal character of 'legal interest' protected under Article 62 of the Statute of the International Court of Justice by the mechanism of intervention, the Court required the 'interest relied upon by the State seeking to intervene to be of a legal nature, in the sense that this interest has to be the object of a real and concrete claim of that State, based on law, as opposed to a claim of a purely political, economic or strategic nature'. See Territorial and Maritime Dispute (Nicar. v. Colom.), Application for Permission to Intervene, 2011 I.C.J 348, 358, para. 26 (4 May) [emphasis added].

15 See for instance Temple of Preah Vihear (Cambodia v. Thai.), Merits, 1962 I.C.J. 6, at 36 (15 June) (observing that ' $\mathrm{t}$ ] $\mathrm{he}$ Parties have also relied on other arguments of a physical, historical, religious and archaeological character, but the Court is unable to regard them as legally decisive').

16 Croatia/Slovenia Arbitration, Award, 2017, 1, at 108, para. 335 (Perm. Ct. Arb, 29 June).

17 See arts 56(1)(a) and 77(1) of the United Nations Convention on the Law of the Sea, 10 December 1982, 1833 U.N.T.S. 397. 
or adjacent countries is concerned, Article 15 of the UNCLOS prescribes the median line except for specific circumstances. These two rules, which possess a customary international law character, pertain more to the law of the sea and do not apply to the acquisition of land sovereignty. Accordingly, they are not addressed here. The air space above land and the maritime areas under sovereignty are also part of the legal concept of 'territory' and therefore the state exercises sovereignty over it. ${ }^{18}$

Territorial disputes, broadly speaking, have been divided in doctrine between disputes as to attribution to territory and dispute relating to the delimitation of boundaries. ${ }^{19}$ This distinction was argued in cases before the Court to invoke a different treatment and different applicable rules. ${ }^{20}$ The critical issue would be the different role that would play effectivités and titles. However, it is now a common understanding that both types of disputes call for the application of the same rules, either specifically conventional or customary rules relating to the acquisition and loss of territorial sovereignty. ${ }^{21}$

Some territorial disputes are about the boundary line separating two sovereignties whereas others relate to isolated territorial areas, such as islands or well-defined territorial areas as a whole. In the Frontier Dispute (Burkina Faso/Niger), a Chamber of the Court explained that 'a boundary represents the line of separation between areas of state sovereignty, not only on the earth's surface but also in the subsoil and in the superjacent column of air'. ${ }^{22}$ As useful as the distinction between disputes as to attribution of territory and boundary disputes could be for descriptive purposes, it has no legal significance whatsoever as far as the application of the rules of international law are concerned. In the Frontier Dispute (Burkina Faso/Mali) case, the judgement clarified that:

The Parties have argued at length over how the present dispute is to be classified in terms of a distinction sometimes made by legal writers between 'frontier disputes' or 'delimitation disputes', and 'disputes as to attribution of territory'. According to this distinction, the former refers to delimitation operations affecting what has been described as 'a portion of land which is not geographically autonomous' whereas the object of the latter is the attribution of sovereignty over the whole of a geographical entity (...) In fact, however, in the great majority of cases, including this one, the distinction outlined above is not so much a difference in kind but rather a difference of degree as to the way the operation in question is

18 On the scope of state sovereignty, see the exhaustive enumeration of the International Court of Justice in Military and Paramilitary Activities in and against Nicaragua (Nicar. v. U.S.), Merits, 1986 I.C.J. 14, 111, paras. 212-3 (27 June).

19 PAUl De LA PRADElle, LA Frontière: Étude De Droit inTERnATIONAL 140-3 (1928), who distinguished between disputes relating to a 'territorial mass' and disputes aiming at 'determining a line'.

20 See Paul Reuter's reply on behalf of Cambodia in Oral submissions for Cambodia, Temple of Preah Vihear (Cambodia v. Thai.) 1962, II I.C.J. Pleadings, at 544-5 (Mar. 26-7). This is also discussed in the Frontier Dispute (Burkina Faso/Mali) case (see below).

21 'The applicable rules of international law relating to boundary disputes are those which are concerned with the resolution of claims of sovereignty over territory'. See Dubai-Sharjah Border Arbitration (Dubai/Sharjah), Award, 1981, 91 I.L.R. 543, at 587 (19 October) [emphasis added].

22 Frontier Dispute (Benin/Niger), Judgment, I.C.J. 90, 205, para. 124 (12 July). 
carried out. The effect of any delimitation, no matter how small the disputed area crossed by the line, is an apportionment of the areas of land lying on either side of the line. ${ }^{23}$

Disputes concerning islands, that by definition would be the subject of disputes 'as to attribution of territory' par excellence, are sometimes settled by a reference to the interpretation of a treaty or other titles, and sometimes depend upon the role of effectivités, as in any other territorial dispute. ${ }^{24}$ Some specificities as to disputes involving islands are motivated by their precise material configuration. Islands are certainly part of state territory and as such, may be appropriated. Controversy frequently appears as to the consideration of pieces of land surrounded by water as islands stricto sensu or 'rocks'. Article 121(3) of the UNCLOS provides that rocks cannot generate an economic exclusive zone or a continental shelf. This discussion does not question whether rocks are islands lato sensu. For the South China Sea Annex VII arbitral tribunal: 'Within Article 121, rocks are a category of island. An island is defined as a "naturally formed area of land," without any geological or geomorphological qualification.' ${ }^{25}$ Rocks are therefore territory and can be as such appropriated. ${ }^{26}$ The question is more difficult as far as low-tide elevations are concerned. In the Qatar/Bahrain case, the Court doubted whether low tide elevations could be considered as territory. The Court explained that:

International treaty law is silent on the question whether low-tide elevations can be considered to be 'territory'. Nor is the Court aware of a uniform and widespread State practice which might have given rise to a customary rule which unequivocally permits or excludes appropriation of low-tide elevations (...) The few existing rules do not justify a general assumption that low-tide elevations are territory in the same sense as islands. It has never been disputed that islands constitute terra firma, and are subject to the rules and principles of territorial acquisition; the difference in effects which the law of the sea attributes to islands and low-tide elevations is considerable. It is thus not established that in the absence of other rules and legal principles, low-tide elevations can, from the viewpoint of the acquisition of sovereignty, be fully assimilated with islands or other land territory. ${ }^{27}$

In the 2012 Territorial and Maritime Dispute (Nicaragua v. Colombia), the Court is more assertive and dismisses the contention that low-tide elevation can be appropriated as territory. Referring to the abovementioned Qatar/Bahrain decision, the Court maintained that:

It is well established in international law that islands, however small, are capable of appropriation. By contrast, low-tide elevations cannot be appropriated, although 'a coastal State has sovereignty over low-tide elevations which are situated within its territorial sea, since it has sovereignty over the territorial sea itself' and low-tide elevations within

23 Frontier Dispute (Burkina Faso/Mali), Merits, 1986 I.C.J. 554, 563, para. 17 (22 December).

24 See Chapter 4 of this Research Handbook.

25 South China Sea Arbitration (Phil./China), Final Award, Annex VII Tribunal, 2016, 1, at 206, para. 481 (12 July).

26 Maritime Delimitation and Territorial Questions between Qatar and Bahrain (Qatar v. Bahr.), Merits, 2001 I.C.J. 40, 102, para. 206 (16 March).

27 Id., at 101-2, paras. 205-6. 


\section{Research handbook on territorial disputes in international law}

the territorial sea may be taken into account for the purpose of measuring the breadth of the territorial sea. ${ }^{28}$

It was in accordance with this narrow interpretation that the Court abstained from deciding which state from Malaysia or Singapore has sovereignty over South Ledge, in spite of the explicit request by the parties to do so. The Court considered that South Ledge, as a low tide elevation, belongs to the state in the territorial waters of which it is located. Since the parties did not specifically ask the Court to draw the line of delimitation of the territorial waters of the parties, it found that it could not decide who the sovereign of it was. ${ }^{29}$

Boundary disputes, for their part, may arise at different stages of the process leading to determining a boundary. The stages of the process include the delimitation and the demarcation. The Court explained in the Land and Maritime Dispute (Cameroon v. Nigeria):

The delimitation of a boundary consists in its 'definition', whereas the demarcation of a boundary, which presupposes its prior delimitation, consists of operations marking it out on the ground. In the present case, the Parties have acknowledged the existence and validity of the instruments whose purpose was to effect the delimitation between their respective territories; moreover, both Parties have insisted time and again that they are not asking the Court to carry out demarcation operations, for which they themselves will be responsible at a later stage. ${ }^{30}$

This Research Handbook deals with all types of territorial legal disputes, whether they relate to the establishment of a boundary line or the determination of sovereignty over an autonomous territory.

\section{Territorial Disputes as Sovereignty Disputes}

As mentioned above, legal territorial disputes are about who is the holder of sovereignty. In the Palmas/Miangas case, Max Huber provided the classical definition of the notion of territorial sovereignty. According to the sole arbitrator in this case:

Sovereignty in the relations between States signifies independence. Independence in regard to a portion of the globe is the right to exercise therein, to the exclusion of any other State, the functions of a State (...) Under this reservation [that of composite States, of collective sovereignty, etc.] it may be stated that territorial sovereignty belongs always to one, or in exceptional circumstances to several States, to the exclusion of all others. ${ }^{31}$

28 Territorial and Maritime Dispute (Nicar. v. Colom.), Judgment, 2012 I.C.J. 624, 641, para. 26 (19 November) [references omitted].

29 Sovereignty over Pedra Branca/Pulau Batu Puteh, Middle Rocks and South Ledge (Malay./Sing), Judgment, 2008 I.C.J. 12, 101, paras. 297-9 (23 May).

30 Land and Maritime Boundary between Cameroon and Nigeria (Cameroon v. Nigeria: Eq. Guinea intervening), Merits, 2002 I.C.J. 303, 359, para. 84 (10 October).

31 Island of Palmas/Miangas (Neth./U.S.), Award, 1928, II R.I.A.A. 829, at 838 (4 April). 
In contemporary international law and international relations, sovereignty is intrinsically linked to a territory, hence the concept of 'territorial sovereignty'. ${ }^{32}$ Only in a territory in which a state enjoys sovereignty does it possess the plenitude and exclusivity of territorial sovereignty. Exercising sovereign competences over the territory of other states requires their consent. In other words, claiming that a territory is under the sovereignty of a state means that this part of the globe was considered as belonging to that state, to the exclusion of other similar subjects. Similar to any other right, the best evidence of being the holder of a title of sovereignty over a territory consists in the capacity to validly alienate or dispose of it under international law.

International practice has used several terms to express the idea that a territory belongs to a state, including terms such as 'ownership' or 'property'. However, territorial sovereignty, as the ultimate title over a territory in international relations, is different from private property rights, which find their legal roots in domestic legal orders. $^{33}$ Certainly, confusion existed in historical periods between territorial sovereignty and the private right of property. As the monarch subsumed in his or her person the legal personality of the state, the title of the sovereign over a territory was often defined using domestic law categories, such as property and ownership. Consequently, in historical periods, a territory could be acquired on the basis of private law institutions, such as marriage and inheritance. ${ }^{34}$ Even in more recent periods, the relation between a state and its territory is often described in terms of ownership. State practice reveals that the expressions such as 'acquisition of ownership over a territory', 'to possess the property of a territory', or 'to have dominium over a territory' are often used to refer to the 'acquisition of territorial sovereignty'.

Nonetheless, territorial sovereignty and property rights are subject to different legal regimes. Whereas the acquisition of property rights in a territory is based upon domestic law - which can later be protected under international law - the acquisition of territorial sovereignty is governed by international law. The distinction between territorial sovereignty and property rights entails several consequences. Firstly, a decision concerning the sovereignty over a territory does not prejudice the rights that individuals or even states may possess therein. Thus, the Chamber in the Frontier Dispute (Benin/Niger) observed 'that the question of the course of the boundary on the bridges is totally independent of that of the ownership of those structures, which belong

32 North Atlantic Coast Fisheries (Gr. Brit./U.S.), Award, 1910, XXI R.I.A.A. 167, at 180 (7 September): 'Considering that the right to regulate the liberties conferred by the Treaty of 1818 is an attribute of sovereignty, and as such must be held to reside in the territorial sovereign, unless the contrary be provided; and considering that one of the essential elements of sovereignty is that it is to be exercised within territorial limits, and that, failing proof to the contrary, the territory is coterminous with the Sovereignty, it follows that the burden of the assertion involved in the contention of the United States (viz. that the right to regulate does not reside independently in Great Britain, the territorial Sovereign) must fall on the United States.'

33 Thus the Court emphasized in Pedra Branca/Pulau Batu Puteh that "in law "ownership" is distinct from "sovereignty", albeit it noticed that, depending on the circumstances the two terms may be used to refer to sovereignty. See Sovereignty over Pedra Branca/Pulau Batu Puteh, Middle Rocks and South Ledge (Malay./Sing), Judgment, 2008 I.C.J. 12, 80 para. 122 (23 May).

34 See J. H. W. VerziJl, International LaW in Historical Perspective, volume 3 (STATE TERRITORY) 298-325 (1970). 


\section{Research handbook on territorial disputes in international law}

to the Parties jointly'. ${ }^{35}$ Secondly, states may possess property rights in territories belonging to another state. For instance, the Mundat Forest, which is under German sovereignty, nonetheless belongs to France, ${ }^{36}$ and the region of Naharayim Baqura, which is under Jordanian sovereignty but is Israeli property. ${ }^{37}$ Similarly, the region of Tiwinza, which is under Peruvian sovereignty, is owned by the Republic of Ecuador. ${ }^{38}$ Thirdly, a transfer of property does not necessarily entail a transfer of sovereignty and vice versa. More specifically, a transfer of the sovereignty over a territory to another state does not affect private property rights that are held in good faith. ${ }^{39}$

From an international law perspective, claiming that a given entity enjoys territorial sovereignty means that it possesses the ultimate title over this territory. As such, territorial sovereignty is different from other minor competences that a state may have over a territory. In some circumstances, a state may administer a territory without being its sovereign. Consequently, one should strictly differentiate titles of territorial sovereignty from titles of administration, as will be examined in Chapter 4 of this Research Handbook. Titles of administration cover four main hypotheses, which all fall short of the possession of the sovereignty over a territory. Firstly, under Article 22 of the League of Nations Covenant or Chapter XII of the UN Charter, states that exercised a mandate or a trusteeship were entitled to administer the territories without having acquired sovereignty over the territories in question. This title was based on the agreements concluded with the League of Nations and the UN respectively. ${ }^{40}$ In the same vein, after the consecration of the right of self-determination as a norm of public international law, the titles of sovereignty that were possessed by colonial powers fell into obsolescence and were transformed into simple titles of administration of the territory pending its decolonization. Thus, Resolution 2625 of the General Assembly clarified that:

35 Frontier Dispute (Benin/Niger), Judgment, 2005 I.C.J. 90, 141-2, para. 124 (12 July).

36 See the Exchange of notes between France and the Federal Republic of Germany of 10 May 1984, 89 Revue GÉnÉRALE DE Droit InTERnATIONAl Public 585-8 (1985).

37 Art. 3(8) of the Treaty of Peace between Israel and Jordan of 26 October 1994, 34 (1) I.L.M. 46, 47 and 56-7.

38 See the Pronunciamiento vinculante de los Jefes de Estado de los Países Garantes of 23 October 1998 and the Acta Presidencial of 26 October 1998, available at http://plan binacional.gob.ec/wp-content/uploads/2016/03/1-acuerdo-de-paz.pdf.

39 Settlers of German Origin in Poland, Advisory Opinion, 1923 P.C.I.J. (ser. B) No. 6, at 36 and 38 (10 September); German Interests in Polish Upper Silesia (Ger. v. Pol.), 1926 P.C.I.J. (ser. A) No. 7, at 22 and 42 (25 May); Land, Island and Maritime Frontier Dispute (El Sal./Hond.: Nicar. intervening), Judgment, 1992, I.C.J. 351, 400-401, para. 66 (11 September); Frontier Dispute (Benin/Niger), Judgment, 2005 I.C.J. 90, para. 118 (12 July).

40 Thus, the Court explained in the International Status of South West Africa advisory opinion: 'The terms of this Mandate, as well as the provisions of Article 22 of the Covenant and the principles embodied therein, show that the creation of this new international institution did not involve any cession of territory or transfer of sovereignty to the Union of South Africa. The Union Government was to exercise an international function of administration on behalf of the League, with the object of promoting the well-being and development of the inhabitants.' International Status of South West Africa, Advisory Opinion, 1950 I.C.J. 128, 132 (11 July). 
The territory of a colony or other Non-Self-Governing Territory has, under the Charter, a status separate and distinct from the territory of the State administering it; and such separate and distinct status under the Charter shall exist until the people of the colony or Non-SelfGoverning Territory have exercised their right of self-determination in accordance with the Charter, and particularly its purposes and principles. ${ }^{41}$

Secondly, a state may confer to another the power to administer a territory under its sovereignty. A classic example of a treaty establishing an administration is the lease treaty between China and the United Kingdom with respect to Hong Kong. ${ }^{42}$ Similarly, the Guantanamo Bay treaty grants the United States the title of administration of the said territory while maintaining it under the sovereignty of Cuba. ${ }^{43}$ Rights of administration can also result from a decision of an international organization or a peace conference. Thirdly, under international humanitarian law, an occupying power is entitled to exercise a limited number of competences over a territory, especially for the benefit of the population that has fallen under its control following the armed conflict. ${ }^{44}$ However, this does not mean that the occupying power is entitled to administer the territory. International Humanitarian Law only confers such competences insofar as the factual military occupation lasts. Fourthly, in historical periods protectorates and suzerainty agreements also granted power limited competences over the territory under protectorate or suzerainty. Thus, in the Nationality Decrees in Tunisia and Morocco, the Court rejected the claim of France that it possessed the plenitude of competences in its Moroccan protectorate. For the Court:

The extent of the powers of a protecting State in the territory of a protected State depends, first, upon the Treaties between the protecting State and the protected State establishing the Protectorate, and, secondly, upon the conditions under which the Protectorate has been recognised by third Powers as against whom there is an intention to rely on the provisions of these Treaties. In spite of common features possessed by Protectorates under international

41 Declaration on Principles of International Law concerning Friendly Relations and Co-operation among States in accordance with the U.N. Charter, G.A. Res. 2625, U.N. Doc. A/RES/25/2625 (Oct. 24, 1970).

42 See Convention between the United Kingdom and China respecting an extension of Hong Kong Territory, June 9, 1898, in 21 Hertslet's COMMERCial Treaties: A COMPLete Collection of the Treaties and Conventions, and Reciprocal Regulations, at PResent Subsisting BetweEn Great Britain AND Foreign Powers 293-4 (1840). 'It has been agreed between the Governments of Great Britain and China that the limits of British Territory shall be enlarged under lease to the extent indicated generally on the annexed map. The exact boundaries shall be hereafter fixed when proper surveys have been made by officials appointed by the two Governments. The term of this lease shall be ninety-nine years.'

43 See Articles 1 to 3 of the Agreement Between the United States and Cuba for the Lease of Lands for Coaling and Naval stations; February 16/23, 1903 in INTER-AMERICAN RELATIONS; COLLECTION OF DOCUMENTS, LEGISLATION, DESCRIPTIONS OF INTER-AMERICAN ORGANIZATIONS, AND OTHER MATERIAL PERTAINING TO INTER-AMERICAN AFFAIRS 583-4 (Barry Sklar and Virginia M. Hagen eds., 1972).

44 See notably, Section III (Military authority over the territory of the hostile State) of Convention (IV) respecting the Laws and Customs of War on Land and its annex: Regulations concerning the Laws and Customs of War on Land, Oct. 18, 1907. 


\section{Research handbook on territorial disputes in international law}

law, they have individual legal characteristics resulting from the special conditions under which they were created, and the stage of their development. ${ }^{45}$

Territorial sovereignty as the ultimate title with respect to a territory allows it to account for different socio-cultural systems in the world and the different forms through which it manifested itself throughout various historical periods over the centuries. During colonial expansion, colonial powers also acknowledged the titles of non-European political entities to the sovereignty over their territory. The multiple treaties of cession of sovereignty between the two parties illustrate this point. Chapters 2 and 3 of the Research Handbook discuss this practice, as well as the means through which colonial powers proceeded to extinguish local titles of territorial sovereignty. Although exceptional in practice, private persons acquired titles of territorial sovereignty during colonial expansion without express mandates of their sovereigns. ${ }^{46}$ In contemporary international law, only states and peoples can possess territorial sovereignty. As far as states are concerned, they outlived their other competitors to impose themselves as the primary subjects of international law and the main actors in international relations. ${ }^{47}$ The capacity of states to hold titles of territorial sovereignty is a matter that is currently beyond discussion. Actually, a territory is, as expressed by the Montevideo Convention on Rights and Duties of States, one of the constitutive elements of a state that set this particular form of political organization apart. ${ }^{48}$ As far as peoples are concerned, their consecration as subjects of international law is more recent, and dates from the emergence of the right to self-determination as a fundamental principle of international law of jus cogens character, ${ }^{49}$ applicable erga omnes. ${ }^{50}$ Thus, even peoples that have not yet established themselves as states enjoy sovereignty over their territories. Reflecting this perception, the practice of the UN General Assembly and the Security Council to adopt resolutions condemning acts infringing the territorial integrity of peoples reveals this perception of the international community. ${ }^{51}$

45 Nationality Decrees Issued in Tunis and Morocco on Nov. 8th, 1921, Advisory Opinion, 1923 P.C.I.J. (ser. B) No. 4, at 27 (7 February).

46 See for instance the Dent Overbeck donation that the Court summarily examines in Sovereignty over Pulau Ligitan and Pulau Sipadan (Indon./Malay.), Application for Permission to Intervene, 2001 I.C.J. 575, 599, paras. 65-6 (23 October). See also the agreement between Sir James Brooke and the Sultan of Borneo with respect to Sarawak, discussed in MARK F. LiNDLEY, THE ACQUISITION AND GOVERNMENT OF BACKWARD TERRITORY IN INTERNATIONAL LAW 86-8 (1926).

47 See an account of this historical event in Hendrik SPRUYt, The SOVEREIGN STATE AND ITS COMPETITORS: An ANALYSIS OF SySTEMS ChANGE (1994).

48 Art. 34 of the Convention on Rights and Duties of States adopted by the Seventh International Conference of American States, 26 December 1933, 165 L.N.T.S. 19.

49 Accordance with international law of the unilateral declaration of independence in respect of Kosovo, Advisory Opinion, 2010 I.C.J. 403, 437, para. 81 (22 July) (characterizing a certain number of resolutions, including resolutions 216 and 217 of the Security Council, which dealt with the right of self-determination, as sanctioning 'other egregious violations of norms of general international law, in particular those of a peremptory character').

50 East Timor (Port. v. Austl.), Judgment, 1995, I.C.J. 90, 102, para. 29 (30 June).

51 See for example, S.C. Res. 389, U.N. Doc. S/RES/389 (Apr. 22, 1976) with respect to East Timor and G.A. Res. 33/24, U.N. Doc. A/RES/33/24 (Nov. 29, 1978) mentioning 'the right 
Interestingly, these two UN organs did not distinguish whether such conduct was carried out by colonial powers or newly independent states. More concretely, the General Assembly adopted resolutions sanctioning the manoeuvres of colonial powers to keep hold of their territories, even before their independence. ${ }^{52}$

This Research Handbook refers to disputes as to the sovereignty over territory, and takes into account the distinction between sovereignty and other competences over territory as well as the different holders of territorial sovereignty.

\section{THE LAW APPLICABLE TO TERRITORIAL DISPUTES}

The international law rules applicable to the establishment of sovereignty over territory are different from those applicable to areas falling under the maritime jurisdiction of states, such as the economic exclusive zone and the continental shelf. For these maritime areas, treaty law, case law and practice have consecrated the rule searching for an equitable result, involving a method of three steps that uses equidistance as the starting point, then taking into account relevant circumstances in order to modify the former is necessary, also employing a disproportionality test. ${ }^{53}$ Thus, these different spaces are governed by different rules. While the law applicable in the field of maritime delimitation is codified in a binding instrument - the 1982 UN Convention on the Law of the Sea, the establishment of territorial sovereignty is essentially governed by un-codified customary rules. ${ }^{54}$ The role of equity and the impact of the relationship between titles/effectivités is also different in territorial disputes from in maritime delimitation ones. However, land and maritime boundaries also share some common rules: the applicability of uti possidetis, ${ }^{55}$ the principle of stability and finality of boundaries $^{56}$ and the impossibility to invoke the clausula rebus sic stantibus ${ }^{57}$ are equally applicable to both kinds of boundaries.

of all peoples under alien and colonial domination to self-determination, national independence, territorial integrity, and national unity and sovereignty without external interference'.

52 For example, G.A. Res. 2066 (XX), U.N. Doc. A/RES/2066 (XX) (Dec. 16, 1965) with respect to Mauritius.

53 See a clear restatement of the rules in this respect in, Maritime Delimitation in the Black Sea (Rom. v. Ukr.), Judgment, 2009 I.C.J. 61, 101-3, paras. 115-22 (3 February).

54 Besides the aborted attempt of the International Law Commission mentioned in the Introduction of this Research Handbook, see also American Institute of International Law, Projects No 10 (National Domain) and No 11 (Rights and Duties of Nations in Territories in Dispute on the Question of Boundaries), 20 AM. J. INT'L L. SPEC. SuP. 318-22 (1926).

55 See Marcelo Kohen, L'uti possidetis et les délimitations maritimes, in LE PROCES INTERNATIONAL: LIBER AMICORUM JEAN-PIERRE COT 155-70 (2009).

56 Aegean Sea Continental Shelf (Greece v. Turk.), Judgment, 1978 I.C.J. 3, 35-6, para. 85 (19 December).

57 Art. 62(2)(a) of the Vienna Convention on the Law of Treaties, May 26, 1969, 1155 U.N.T.S. 331. 


\section{A. A Method to Analyse Territorial Disputes from a Legal Perspective}

Taking into account the customary rules as applied in case law and practice, it is possible to draw a specific method for the settlement of territorial disputes. Firstly, the judge or arbitrator (but also any person interested in appreciating how a territorial dispute would be settled) will establish the relevance of one of the titles invoked by the parties and then its materiality. The existence of a treaty that settles the question will hold first and foremost his or her attention. This is generally the case of any dispute, as it emerges from Article 38 (1) of the Statute of the International Court of Justice. A treaty regulating the question at issue would constitute the lex specialis and hence there would be no need to start with the analysis of general international law rules. ${ }^{58}$ The absence of a treaty will on the contrary require the search for a title in general international law. This may be effective occupation, uti possidetis or any other title, whose exact nature will depend on the situation. Secondly, after establishing the relevant title for the determination of the solution of the dispute and applying it, the subsequent conduct of the parties will be examined to determine whether such conduct has changed the legal situation existing by virtue of the title, or whether it has simply confirmed that situation. In reality, this approach only aims at confirming that no change has occurred. It is clear that if the judge has found in the later behaviour of the parties how to resolve the dispute, he may begin his analysis there without necessarily dealing with the previous situation. As will be discussed in Chapter 4, effectivités contrary to the title do not per se dispose of it. Thirdly, the technical rules of the critical date and the intertemporal law will be useful in relation to the two previous steps. Fourthly, equity infra legem will be taken into account only if it proves necessary for the interpretation of the title in presence, especially in case of lack of clarity of the title or insufficiency of proof. ${ }^{59}$

As mentioned above, in maritime delimitation disputes, equity is part of the applicable law. Equity plays a slightly different role in territorial disputes. In the Frontier Dispute (Burkina Faso/Mali) case, the judgement distinguished between equity contra legem, praeter legem and equity infra legem. The Court recognized the relevance of equity infra legem, that is to say the equity arising from the mere application of the law, in determining territorial boundaries. However, the Court remained adamant that equity contra legem had no place in territorial disputes, except with the consent of the parties to the dispute. ${ }^{60}$ Thus, the Court clarified that:

[T]he Chamber can resort to that equity infra legem, which both Parties have recognized as being applicable in this case (...). In this respect the guiding concept is simply that 'Equity as a legal concept is a direct emanation of the idea of justice' (...). The Chamber would however stress more generally that to resort to the concept of equity in order to modify an established

58 See for instance, Territorial Dispute (Libya v. Chad), Judgment, 1994 I.C.J. 6, 38-40, paras. 75-6 (3 February).

59 See an analysis of this method in Marcelo Kohen, Le règlement des différends territoriaux à la lumière de l'arrêt de la C.I.J. dans l'affaire Libye/Tchad, 100 (2) REVUE GÉNÉRALE DE DROIT INTERNATIONAL PUBLIC 301-4 (1995).

60 Frontier Dispute (Burk. Faso/Mali), Judgment, 1986 I.C.J. 554, 567-8, para. 28 (22 December). 
frontier would be quite unjustified. Especially in the African context, the obvious deficiencies of many frontiers inherited from colonization, from the ethnic, geographical or administrative standpoint, cannot support an assertion that the modification of these frontiers is necessary or justifiable on the ground of considerations of equity. These frontiers, however unsatisfactory they may be, possess the authority of the uti possidetis and are thus fully in conformity with contemporary international law. Apart from the case of a decision ex aequo et bono reached with the assent of the Parties, 'it is not a matter of finding simply an equitable solution, but an equitable solution derived from the applicable law'. It is with a view to achieving a solution of this kind that the Chamber has to take account, not of the agreement of 15 January 1965 , but of the circumstances in which that agreement was concluded. ${ }^{61}$

Consequently, the Chamber of the Court applied equity infra legem only when it found that there was no evidence as to the administrative delimitations of the pools of Soum and In Abao and thus divided them equitably into two parts, to divide their maximum area during the rainy season equally between the parties. ${ }^{62}$ Another Chamber of the Court, in the El Salvador/Honduras case, also applied equity infra legem in the fourth sector of the boundary under dispute when it found that the uti possidetis line in the area between Malpaso de Similatón and the Negro-Quiagara river was impossible to identify. ${ }^{63}$

Except for the situation in which a territorial dispute is essentially governed by a treaty that specifically determines the status of the territory concerned, the general international law rules applicable to these disputes are those governing the acquisition and loss of territorial sovereignty, the fundamental principles of international law and some technical rules, such as the critical date and the intertemporal law. The Research Handbook covers them systematically. Chapters 2 and 3 of the Research Handbook review different titles that allegedly established the sovereignty of colonial powers over the territories of non-European political entities at the time of the European expansion of sovereignty all around the world. Taking into account the distinction between original and derivative titles of territorial sovereignty, Chapter 2 examines original titles whereas Chapter 3 focuses on derivative titles. Chapter 4 addresses the role of two essential notions in this field, that is to say, titles and effectivités, and explains the content and different kinds of titles as well as the different manifestations of effectivités and the inter-relationship between titles and effectivités. A list of titles of territorial sovereignty is included in Chapter $4 .{ }^{64}$ The impact of fundamental principles on international law in territorial disputes is briefly analysed in the following section. Chapters 7 to 10 address the relevance of these principles. Finally, Chapters 11 and 12 cover the technical rules applicable in the settlement of territorial disputes.

A separate question is the territorial extension and the boundaries of newly created states. In the case of decolonization, there is no doubt that the principle of uti possidetis iuris is applicable. The newly independent state succeeds to the territorial extension of

$61 \quad I d$., at 563 , para. 17.

$62 I d$., at 633 and 640, paras. 150 and 162.

63 Land, Island and Maritime Frontier Dispute (El Sal./Hond.: Nicar. intervening), Judgment, 1992, I.C.J. 351, 514, para. 262 (11 September).

64 See page 151 of this Research Handbook. 
the relevant prior administrative unit or units during colonial times. ${ }^{65}$ The same rule has been followed in the last cases of dismemberment of federal states. Chapter 8 deals with these issues, and examines the large practice in the area.

\section{B. The Relevance of Fundamental Principles of International Law in Territorial Disputes}

Developing the foundational principles of the UN Charter, GA Resolution 2625 (XXV) lists the fundamental principles of the current international legal order. ${ }^{66}$ Among the fundamental principles of the contemporary international legal order, four principles are of the most significant importance, respectively, the respect for the territorial integrity, the prohibition of the use of force in international relations, the right of peoples to self-determination and the obligation to settle international disputes through peaceful means.

\section{The principle of territorial integrity}

The Court emphasized the importance of the principle of the respect for the territorial integrity in international relations on several occasions. In the Corfu Channel (UKv. Albania) case, the Court explained that '[b]etween independent States, respect for territorial sovereignty is an essential foundation of international relations'. ${ }^{67}$ Some years later, the Court reaffirmed 'the duty of every State to respect the territorial sovereignty of others' ${ }^{68}$ In the Kosovo advisory opinion, the Court observed that, 'the principle of territorial integrity is an important part of the international legal order' ${ }^{69}$ The principle is enshrined in Article 2(4) of the UN Charter. Although it is linked to the principle of the prohibition of the use of force, the principle of territorial integrity is an autonomous principle also applicable beyond the context of its breach by the use of force. The 1970 Declaration on Principles of International Law Concerning Friendly Relations links it to the principle of equal sovereignty of states, mentioning that ' $[\mathrm{t}]$ he territorial integrity and political independence of the State are inviolable'. Respect for territorial integrity is also linked with the principle of self-determination in this instrument. ${ }^{70}$ The 1975 Final Act of Helsinki of the Conference on Security and Cooperation in Europe mentioned it autonomously among the ten principles guiding relations between participant states. It also included the principle of the

\footnotetext{
65 Frontier Dispute (Burk. Faso/Mali), Merits, 1986 I.C.J. 554, 565, para. 20 (22 December).

66 Declaration on Principles of International Law concerning Friendly Relations, supra note 41.

67 Corfu Channel (U.K and N. Ir. v. Alb.), Merits, 1949 I.C.J. 4, 35 (9 April).

68 Military and Paramilitary Activities in and against Nicaragua (Nicar. v. U.S.), Merits, 1986 I.C.J. 14, 111, and 128, para. 213 and paras. 251-2 respectively (27 June).

69 Accordance with International Law of the Unilateral Declaration of Independence in Respect of Kosovo, Advisory Opinion, 2010 I.C.J. 403, 437 para. 80 (20 July).

70 Declaration on Principles of International Law concerning Friendly Relations, supra note 41, at para. (d).
} 
inviolability of boundaries, ${ }^{71}$ although this one could be subsumed in that of territorial integrity. ${ }^{72}$ The principle of the respect for the territorial integrity of states is also found in a considerable number of other international instruments, whether bilateral or multilateral.

As far as territorial disputes are concerned, the principle of territorial integrity protects the holder of sovereignty against infringements imputable to another subject of international law. It essentially entails a mutual guarantee that the different subjects of international law commit not to undermine each other's territorial sovereignty. It implies first that any encroachment on the territorial sovereignty of another subject is an internationally wrongful act. Any effectivités accomplished in this context is 'contra legem' as the Court characterized them in Land and Maritime Boundary (Cameroon v. Nigeria; Equatorial Guinea intervening). ${ }^{73}$ This last point is important for the establishment of sovereignty over territories already having a master. The principle of respect for territorial integrity thus supports the idea that no acquisition of territory already having a master can be made without the consent of its sovereign, as will be detailed in Chapter 4.

There is controversy about the applicability of the principle of territorial integrity to non-state actors. In the Kosovo advisory opinion, the Court adopted a very restrictive reading of the formulation of the principle in the UN Charter and in Resolution 2625 $(\mathrm{XXV})$, considering that it is only applicable in inter-state relations. ${ }^{74}$ However, these two legal instruments define the principle of territorial integrity broadly as applicable in 'international relations'. Two questions may be discussed. One question is whether the holders of the protection are only states or whether other entities are also equally protected. The other question is whether the obligation to respect the territorial integrity is opposable to non-state actors. With regard to the first question, practice shows that in the context of decolonization, colonial powers were criticized for disrupting the territorial integrity of colonies with the purpose of keeping part of these territories under their control after the accession of independence of their former colonies. ${ }^{75}$ This is the main aspect of the advisory opinion requested by the General Assembly to the

71 Conference on Security and Cooperation in Europe, Final Act, Helsinki, 1 August 1975, available at http://www.osce.org/helsinki-final-act?download=true.

72 Certain Activities Carried Out by Nicaragua in the Border Area (Costa Rica v. Nicar.), Judgment, 2015, I.C.J. 665, 1, para. 4 (16 December) (Separate Opinion of Vice-President Judge Abdulqawi Yusuf) (considering that '[ $\mathrm{t}]$ he inviolability of boundaries is indeed a basic element of the broader principle of territorial integrity').

73 Land and Maritime Boundary between Cameroon and Nigeria (Cameroon v. Nigeria: Eq. Guinea intervening), Merits, 2002 I.C.J. 303, 351, para. 64 (10 October).

74 Accordance with International Law of the Unilateral Declaration of Independence in Respect of Kosovo, Advisory Opinion, 2010 I.C.J. 403, 437 para. 80 (20 July).

75 This is the case of the separation of the Chagos Archipelago from Mauritius (G.A. Res. 2066 (XX), U.N. Doc. A/RES/2066 (XX) (Dec. 16, 1965)), the Glorieuses, Juan de Nova, Europa and Bassas da India Islands from Madagascar (Resolution 34/91 of the General Assembly of 12 December 1979) and Mayotte from Comoros (Resolution $31 / 4$ of the General Assembly of 21 October 1976). 
International Court of Justice on the Legal consequences of the separation of the Chagos Archipelago from Mauritius in 1965.76

The second question, namely whether international law imposes the respect of territorial integrity to non-state actors pertains to the more general question relating to the legal regime applicable to secession in international law. ${ }^{77}$ It must be recalled that cases of creation of newly independent states in the context of the exercise of the right to self-determination of peoples under colonial or foreign domination are not cases of secession. There is therefore no conflict between the exercise of the right of self-determination and the principle of territorial integrity, simply because the colonial territories or under alien occupation are not part of the territories of the administering state, as the above-quoted excerpt of Resolution 2625 shows.

The question arises only in the cases of attempts at secession within existing states. On the one hand, the seceding movement or entity, unlike peoples subject to colonial or alien subjugation, domination and exploitation, does not possess a right to independence by virtue of international law and is not considered a subject of international law. ${ }^{78}$ On the other hand, nothing has extinguished the state's title of sovereignty in the area claimed by the seceding entity or movement. The common idea is that since the secessionist movements or entities are not subjects of international law, the international obligation of respecting the territorial integrity of the state cannot be opposed to them. This may be the case, since the matter can be seen as being governed by the domestic law of the state concerned. ${ }^{79}$ However, recent international practice shows that in cases of forcible attempts at secession both the UN and regional bodies have invoked the need for all the parties concerned by the internal conflict to respect the territorial integrity of the states concerned. ${ }^{80}$

\section{The prohibition of the use of force}

The development of the international law rules restricting the right to use force is usually described by reference to the 1907 Drago-Porter Convention (Second Hague Convention Respecting the Limitation of the Employment of Force for the Recovery of Contract Debts), the Covenant of the League of Nations, the Briand-Kellogg Pact (Paris

76 See Request for an advisory opinion of the International Court of Justice on the legal consequences of the separation of the Chagos Archipelago from Mauritius in 1965, G.A. Res. 71/292, U.N. Doc. A/RES/71/292 (June 22, 2017).

77 See Chapter 8 and in general Marcelo G. Kohen (ED), SECESSION: InTERnAtional LaW PERSPECTIVES (2006).

78 Accordance with International Law of the Unilateral Declaration of Independence in Respect of Kosovo, Advisory Opinion, 2010 I.C.J. 403, 436, para. 79 (20 July).

79 This is the position adopted by the International Court of Justice in the Kosovo Advisory Opinion, id., at 437 , para. 80.

80 See the cases of Cyprus [G.A. Res. 37/253, U.N. Doc A/RES/37/253 (May 13, 1983), S.C. Res. 1251, U.N. Doc S/RES/1251 (June 29, 1999)], Bosnia-Herzegovina [S.C. Res. 752 (1992), S.C. Res. 770 (1992), S.C. Res. 787 (1992), S.C. Res. 836 (1993), S.C. Res. 847 (1993), S.C. Res. 859 (1993), S.C. Res. 942 (1994) and S.C. Res. 982 (1995)], Croatia [S.C. Res. 981 (1995)], Serbia [S.C. Res. 1160 (1998), S.C. Res. 1203 (1998) and S.C. Res. 1244 (1999)], Somalia [(S.C. Res. 1772 (2007)], Georgia [S.C. Res. 1781 (2007) and S.C. Res. 1808 (2008)], the Democratic Republic of the Congo [S.C. Res. 1756 (2007)] and Sudan [S.C. Res. 1769 (2007)], among others. 
Convention of 1928) and the Charter of the UN. In reality, this evolution began well before, at the universal and the regional levels. In the field that interests us, a way of restricting the use of force consists in limiting the consequences that flow from it, whether military victory or defeat. It is beyond doubt that since 1945 the use of force is prohibited as a means of both acquiring territorial sovereignty and solving territorial disputes. $^{81}$ The only unilateral use of force that is authorized by the UN Charter is the inherent right of self-defence. The contemporary legal regime, therefore, excludes any use of force in territorial disputes, irrespective of the validity of the titles claimed by the parties. The state actually controlling a territory at the moment of the dispute is protected from being dislodged of it by the prohibition of the use of force. In this regard, such dispute has to be settled only through the use of the peaceful dispute settlement mechanisms listed in Article 33 of the UN Charter. Chapter 5 of the Research Handbook discusses the relationship between territorial disputes and the use of force or its threat.

The authors of Chapter 5 rightfully question the validity of the conventional history on the prohibition of the use of force before 1945. However, the scope of conquest during that period deserves some development. Doctrinal analysis, including during that period, did not reflect what occurred in international practice. On the one hand, the use of force without a lawful cause of war was always considered as being contrary to international law. The legality of a use of force depended on the existence of a formal war and a just cause of war, especially an injury to one's rights. Chapter 3 discusses the different frameworks governing the use of force in this period in relation to the acquisition of territorial sovereignty through the use of force against local political entities outside Europe. In the nineteenth century, the principle of territorial integrity was used to condemn the use of force. ${ }^{82}$ On the other hand, conquest never operated as an autonomous and independent title of territorial sovereignty, except for the case of debellatio. In cases of debellatio, the disappearance of the state or local political entity concerned extinguished any claim to its territory. When, however, the state or local political entity concerned survived the military defeat an additional element was necessary to turn military possession into a lawful title of a territorial sovereignty. Thus, the arbitral award in the Ottoman Public Debt case explains: 'Quels que soient les effets de l'occupation d'un territoire par l'adversaire avant le rétablissement de la paix, il est certain qu'à elle seule cette occupation ne pouvait opérer juridiquement le transfert de souveraineté.' 83 In the relations between states members of the then

81 Declaration on Principles of International Law concerning Friendly Relations, supra note 41.

82 See Agatha Verdebout, The Contemporary Discourse on the Use of Force in the Nineteenth Century: A Diachronic and Critical Analysis 1 (2) J. USE OF FORCE \& INT'L L. 223-46 (2014).

83 Translation by the editors: 'Whatever the effects of the occupation of a territory by the adversary before the restoration of peace may be, it is certain that this occupation alone could not legally effect the transfer of sovereignty'. See also Affaire de la Dette publique ottomane (Bulgarie/Irak/Palestine/Transjordanie/Grèce/Italie/Turquie), 1925, I R.I.A.A. 529, at 555 (18 April); Affaire des forêts du Rhodope central (fond) (Grèce/Bulgarie), 1933, III R.I.A.A. 1405, at 1428-9 (29 March); Lighthouses in Crete and Samos (Fr. v. Greece), Judgment, 1937 P.C.I.J. (ser. A/B) No. 62, at 101, 103-4 (8 October). 


\section{Research handbook on territorial disputes in international law}

restricted family of Nations, unless the defeated entity consented through a peace treaty, it maintained the sovereignty over its territory. In this regard, the Peace of Utrecht of 1713 is generally regarded as the turning point in the practice of demanding a formal peace treaty to acquire the sovereignty over a territory belonging to the defeated party for the states members of the then restricted community of Nations. ${ }^{84}$

Chapter 3 analyses the situation in the context of the relationship between European states and local entities outside Europe not being recognized as part of the restricted 'European public law' system. It is the subsequent practice of the actors having legal interests in the territory concerned that would determine whether the party successfully using force acquired territorial sovereignty or not. The necessity to examine the subsequent conduct of the parties is even more compelling that in practice states adopted different attitudes with respect to the territory of defeated entities. In some cases, states concluded peace treaties to annex the territory of the defeated entity. In other cases, they did not intend to acquire territorial sovereignty, but only established a military occupation. In other cases, the party winning the armed confrontation did not secure an agreement by which the defeated party ceded the sovereignty of its territory. Often the defeated party also contested claims to its territory made by the state that prevailed during the conflict. In logic, these different situations cannot be put in the same box to consider that military success translated into a title of territorial sovereignty. The relevant test in this respect consists in determining whether the parties having a legal interest in the territory agreed either expressly through a peace treaty, or otherwise to establish a new legal territorial situation.

As military victory and possession of the territory needed to be supplemented by a peace treaty in the relations between members of the then restricted community of states or by the explicit or implicit consent of the defeated local entity outside this context, the editors of this Research Handbook do not consider conquest as a real title of territorial sovereignty.

\section{The principle of self-determination}

In territorial disputes, the human factor can take several forms that do not have the same legal significance. The presence of inhabitants in the disputed territory may have different impacts, sometimes on the outcome of the dispute itself, and in other cases with respect to the protection of the rights of these inhabitants only. Ethnic composition, nationality, wishes, interests and vested rights can be taken into consideration or protected depending on the circumstances. Chapter 9 of this Research Handbook addresses this question. Nothing prevents the parties from establishing human considerations as a parameter for the settlement of their dispute, whether as a general reference to equity contra legem or not. ${ }^{85}$ Practice reveals, however, that states rarely do so, as

84 ARnold DunCAN MCNAiR, Legal EFFeCts of WAR 320 (3rd ed., 1948); Charles ROUSSEAU, LE DROIT DES CONFLITS ARMÉS 136-41 (1983).

85 As part of equity, art. V(3), annex 2 (Agreement on Inter-Entity Boundary Line and Other Related Issues) of the General Framework Agreement for Peace in Bosnia, 14 December, 1995, 35 I.L.M. 111, 113 (1996): 'Unless otherwise agreed by the parties, the proceedings should be conducted in accordance with the UNCITRAL rules. The arbitrators shall apply relevant legal and equitable principles.' 
the arbitral tribunal observed with respect to its own arbitration agreement in the Croatia/Slovenia case. ${ }^{86}$ If no such bilateral rules set out by the parties exist, the dispute is to be settled in the light of general international law.

Although colonial powers cast doubts about the legal character of this principle, ${ }^{87}$ today it is uncontroversial that the principle of self-determination forms part of the fundamental principles of international law. In its Kosovo advisory opinion, the International Court of Justice acknowledged that '[d]uring the second half of the twentieth century, the international law of self-determination developed in such a way as to create a right to independence for the peoples of non-self-governing territories and peoples subject to alien subjugation, domination and exploitation' ${ }^{88}$

The principle of self-determination produces two main legal effects on territorial sovereignty. Firstly, it extinguishes territorial titles, including territorial sovereignty, in contradiction with its recognition. For instance, if colonial powers possessed sovereignty over their colonies, it extinguishes their sovereignty, even if their titles were validly acquired in the past. By virtue of the second rule of intertemporal law, colonial powers are recognized as mere administering states of the colonial territories that they still maintain under their control.

Secondly, from the establishment of self-determination as a principle of international law, peoples that have not yet achieved statehood are also holders of territorial sovereignty. By virtue of their right to self-determination, colonial peoples and peoples under military occupation or under foreign domination possess the right to determine their own status. As a corollary, such peoples possess also the right to dispose of their territory. Their power of disposition ranges from the creation of a newly independent

86 Croatia/Slovenia Arbitration, Award, 2017, 1, at 108-9, paras. 336-9 (Perm. Ct. Arb, 29 June). See specifically para. 339 where the tribunal observes: '[B]oth States are agreed that the course of the boundary should not be determined by the wishes of the inhabitants of the areas in question. The wishes and interests of the inhabitants were, of course, a matter of concern within the political and legal structure of the SFRY and within the mechanisms that were provided for taking those wishes and interests into account when adopting and applying the laws and regulations of the SFRY and of its constituent republics concerning the drawing of boundaries. It is on the basis of those laws and regulations as they stood at 25 June 1991 that the Tribunal must decide.'

87 The British position was summarized as follows: 'it was not before the 1970s, at the earliest, that the United Kingdom accepted that it could be said that the principle of self-determination had become a right under general international law' [Counter-Memorial of the United Kingdom, Chagos Marine Protected Area Arbitration (Mauritius v. U.K.), 2013, para. 7.17 (Perm. Ct. Arb., 15 July)].

88 Accordance with International Law of the Unilateral Declaration of Independence in Respect of Kosovo, Advisory Opinion, 2010 I.C.J. 403, 436 para. 79 (20 July) [referring to Legal Consequences for States of the Continued Presence of South Africa in Namibia (South West Africa) notwithstanding Security Council Resolution 276 (1970), Advisory Opinion, 1971 I.C.J. 16, 31-2, paras. 52-3 (21 June)]; East Timor (Port. v. Austl.), Judgment, 1995, I.C.J. 90, 102, para. 29 (30 June); Legal Consequences of the Construction of a Wall in the Occupied Palestinian Territory, Advisory Opinion, 2004 I.C.J. 136, 171-2, para. 88 (9 July). 
state, to their integration or free association with a new or an existing state. ${ }^{89}$ Conversely, human groups that are not characterized as peoples under international law do not possess a right of deciding the fate of the territory they inhabit. In this respect, the notion of 'people' is defined neither through self-qualification nor through socio-cultural criteria. In other words, not every population inhabiting a territory constitutes a people from the perspective of the right of self-determination. ${ }^{90}$ International law distinguishes different types of human communities with different rights. Peoples, minorities and indigenous peoples are three legal categories whose existence in a given territory implies different consequences as to the possibility to decide about territorial sovereignty. Only 'peoples', in the international legal sense of the word, are holders of the right to self-determination.

Undoubtedly, the right of self-determination applies to peoples under colonial regime, military occupation and foreign domination since in these circumstances they are deprived of the possibility of exercising that right. Outside of this context, the notion of people applies to the entire population inhabiting an independent state. The exception to this is when a state recognizes proprio motu that it is composed of several peoples entitled to exercise their right of self-determination. ${ }^{91}$

Outside the principle of self-determination, the human factor still plays an important role in territorial disputes today. Not with regard to the fate of the territory, but with respect to the rights and obligations that must be applied and respected with regard to the inhabitants. In the El Salvador/Honduras case, the Court held that:

The effect of the Chamber's Judgment will however not be that certain areas will 'become' part of Honduras; the Chamber's task is to declare what areas are, and what are not, already part of the one State and the other. If Salvadorians have settled in areas of Honduras, neither that fact, nor the consequences of the application of Honduran law to their properties, can affect the matter. ${ }^{92}$

However, the Chamber had recognized that:

[T] he situation may arise in some areas whereby a number of the nationals of the one Party will, following the delimitation of the disputed sectors, find themselves living in the territory of the other, and property rights apparently established under the laws of the one Party will be

89 See princ. 6 of Principles which should guide members in determining whether or not an obligation exists to transmit the information called for under Article 73e of the Charter, G.A. Res 1541 (XV), U.N. Doc. A/RES/1541(XV).

90 Western Sahara, Advisory Opinion, 1975 I.C.J. 12, 33, para. 59 (16 October) (clarifying that ' $[\mathrm{t}]$ he validity of the principle of self-determination, defined as the need to pay regard to the freely expressed will of peoples, is not affected by the fact that in certain cases the General Assembly has dispensed with the requirement of consulting the inhabitants of a given territory. Those instances were based either on the consideration that a certain population did not constitute a "people" entitled to self-determination or on the conviction that a consultation was totally unnecessary, in view of special circumstances.') [emphasis added].

${ }_{91}$ See for instance, Article 39 paragraph 1 of the Ethiopian Constitution (available at http://www.wipo.int/edocs/lexdocs/laws/en/et/et007en.pdf) which stipulates that '[e]very Nation, Nationality and People in Ethiopia has an unconditional right to self-determination, including the right to secession'.

92 Land, Island and Maritime Frontier Dispute (El Sal./Hond.: Nicar. intervening), Judgment, 1992, I.C.J. 351, 419, para. 97 (11 September). 
found to have been granted over land which is part of the territory of the other. The Chamber has every confidence that such measures as may be necessary to take into account of this situation will be framed and carried out by both Parties, in full respect for acquired rights, and in a humane and orderly manner. ${ }^{93}$

In the Cameroon v. Nigeria case, the nationals of the parties had occupied villages located on the other side of the boundary. The Court reaffirmed that:

[I]t has no power to modify a delimited boundary line, even in a case where a village previously situated on one side of the boundary has spread beyond it. It is instead up to the Parties to find a solution to any resultant problems, with a view to respecting the rights and interests of the local population. ${ }^{94}$

In the same case, the Court dismissed the relevance of services that Nigeria had provided to the inhabitants of the disputed territory. Although qualifying as effectivités, these Nigerian actions came up against the established title of Cameroon over the disputed territory. In such circumstances, preference is to be given to the title. ${ }^{95}$

Human considerations can play a role in territorial disputes when, for the reasons explained above, equity infra legem is applicable. Faced with its duty to make a decision in circumstances in which sovereignty does not appear in a clear manner from the available evidence, the Court can choose a solution that is consonant with human considerations. This is the example mentioned above of the Burkina Faso/Mali case, in which the judgement divided the pools in order to allow equal access to water in these arid regions. In Frontier Dispute (Burkina Faso/Niger), the Court seems also to have been guided by similar considerations when deciding the point in which the boundary line reaches the 'River Sirba at Bossébangou'. The Court observed that there was an indication neither that the boundary line stopped at one or the other of the banks of the river nor that the river was attributed in its entirety to one of the parties. Consequently, the Court held that:

In this regard, the Court notes that the requirement concerning access to water resources of all the people living in the riparian villages is better met by a frontier situated in the river than on one bank or the other. Accordingly, the Court concludes that, on the basis of the Arrêté, the endpoint of the frontier line in the region of Bossébangou is located in the River Sirba. This endpoint is more specifically situated on the median line because, in a

93 Id., at para. 66. In Croatia/Slovenia, the tribunal also noted that in some limited areas (such as the situations described in paragraphs 565 and 630) the course of the boundary, as it results from an application of the law, may not be considered the most practical boundary, whether for reasons of physical or human geography. For the avoidance of doubt, the Tribunal reiterates that, while the present Award fixes the boundary in such areas with binding effect (as the Parties have requested), the Award does not preclude the Parties from subsequently reaching agreement between themselves on practical arrangements concerning the boundary'. Croatia/ Slovenia Arbitration, Award, 2017, 1, at 114, para. 357 (Perm. Ct. Arb, 29 June).

94 Land and Maritime Boundary between Cameroon and Nigeria (Cameroon v. Nigeria: Eq. Guinea intervening), Merits, 2002 I.C.J. 303, 373-4, para. 123 (10 October). See also at 370, para. 107.

$95 I d$., at 415, paras. 222-3. 


\section{Research handbook on territorial disputes in international law}

non-navigable river with the characteristics of the Sirba, that line best meets the requirements of legal security inherent in the determination of a boundary. ${ }^{96}$

Responsibility for breaches of human rights in a given territory is independent from the question of who is the holder of sovereignty. In the Namibia advisory opinion, the Court held that effective control over a territory is the ground of responsibility over a territory, and not the question of the legality of the title. ${ }^{97}$ Similarly, human rights monitoring bodies held that their extraterritorial jurisdiction might cover the acts of states parties to the relevant legal instrument for which they are competent which are committed in foreign or disputed territories. ${ }^{98}$ In the same Namibia advisory opinion, the Court confirmed that the duty of non-recognition of territorial situations established in violation of the fundamental principles of international law does not extend to the acts accomplished to the benefit of private persons. ${ }^{99}$

Finally, a decision on territorial sovereignty is not presumed to affect the vested rights that private persons may have acquired in the disputed territory. After reviewing the relevant case law, the arbitral tribunal in the Abyei case reached the following conclusion:

The jurisprudence of international courts and tribunals as well as international treaty practice lend additional support to the principle that, in the absence of an explicit prohibition to the contrary, the transfer of sovereignty in the context of boundary delimitation should not be construed to extinguish traditional rights to the use of land (or maritime resources). ${ }^{100}$

96 Frontier Dispute (Benin/Niger), Judgment, 2005 I.C.J. 90, 85, para. 101 (12 July).

97 Legal Consequences for States of the Continued Presence of South Africa in Namibia (South West Africa) notwithstanding Security Council Resolution 276 (1970), Advisory Opinion, 1971 I.C.J. 16, 54, para. 118 (21 June): 'South Africa, being responsible for having created and maintained a situation which the Court has found to have been validly declared illegal, has the obligation to put an end to it. It is therefore under obligation to withdraw its administration from the Territory of Namibia. By maintaining the present illegal situation, and occupying the Territory without title, South Africa incurs international responsibilities arising from a continuing violation of an international obligation. It also remains accountable for any violations of its international obligations, or of the rights of the people of Namibia. The fact that South Africa no longer has any title to administer the Territory does not release it from its obligations and responsibilities under international law towards other States in respect of the exercise of its powers in relation to this Territory. Physical control of a territory, and not sovereignty or legitimacy of title, is the basis of State liability for acts affecting other State.'

98 See for instance, Loizidou v. Turkey, Preliminary objections, 310 Eur. Ct. H.R., para. 62 (1995). See also Legal Consequences of the Construction of a Wall in the Occupied Palestinian Territory, Advisory Opinion, 2004 I.C.J. 136, 179-81, paras. 109-13 (9 July).

99 Id., at 56 para. 125: 'In general, the non-recognition of South Africa's administration of the Territory should not result in depriving the people of Namibia of any advantages derived from international Co-operation. In particular, while official acts performed by the Government of South Africa on behalf of or concerning Namibia after the termination of the Mandate are illegal and invalid, this invalidity cannot be extended to those acts, such as, for instance, the registration of births, deaths and marriages, the effects of which can be ignored only to the detriment of the inhabitants of the Territory.'

100 Delimitation of the Abyei Area between the Government of Sudan and the Sudan People's Liberation Movement/Army, Award, 2009, XXX R.I.A.A. 145, para. 263 (Perm. Ct. Arb, 22 July). Concerning maritime delimitation, reference may be made, with certain 
In an earlier application of the rationale underlying this finding, the Permanent Court of International Justice had found that Poland had to respect the rights of private persons of German nationality in the territories that came under its sovereignty after the First World War. ${ }^{101}$ The same was equally true of Austria. In a case between Austria, Hungary and the local railway company of Sopron Köszeg, the arbitral tribunal took the view that:

[I]n principle, the rights of a private company, of an act of concession, cannot be annulled or infringed merely because the territory on which the public service is located has changed its nationality (...) the majority of authors and the solutions of international practice most consistent with the modern conception of the law of nations are in this direction. ${ }^{102}$

A nineteenth-century arbitral award between France and the Netherlands suggests that a distinction exists between the legal regimes applicable in these cases depending on the good faith of the private entity. The arbitral tribunal held:

We declare that the Awa must be considered as a boundary river, to serve as a frontier between the two possessions. By virtue of this arbitration decision, the territory upstream of the confluence of the Awa and Tapanahui rivers must now belong to Holland, without prejudice, however, to the bona fide rights acquired by the French nationals within the territory which had been the subject of the litigation. ${ }^{103}$

\section{The principle of peaceful settlement of disputes}

Parties to a territorial dispute have the obligation to settle it through peaceful means. We have already mentioned that the prohibition of the use of force implies a kind of protection to actual possession, no matter who is right and who is wrong in the dispute. It is not possible to take justice into one's own hands. The obvious problem is that if the possessor rejects any means to settle the dispute peacefully and there is no jurisdictional basis for adjudication, then the recalcitrant party continues with its possession and the other side is unable to settle the dispute. The unsatisfactory situation that has just been noted is in fact indicative of the very nature of the international system, characterized by the absence of centralized bodies and compulsory means of dispute settlement. However, there is necessarily a counterpart: if the holder of sovereignty cannot take justice into its own hands, as long as the other party does not agree to settle the dispute, its titles will be preserved and the other party cannot claim that the mere passing of time changed the legal situation. This is the only logical

reservations, to the award in Maritime Delimitation Procedure (Eri./Yemen) (Second Stage of the Proceedings), Award, 1999, XXII R.I.A.A. 335, at 357-8, paras. 92 and 95 (17 December).

101 Settlers of German Origin in Poland, Advisory Opinion, 1923 P.C.I.J. (ser. B) No. 6, at 36 (10 September); German Interests in Polish Upper Silesia (Ger. v. Pol.), 1926 P.C.I.J. (ser. A) No. 7, at 21 (25 May). See more recently, Frontier Dispute (Benin/Niger), Judgment, 2005 I.C.J. 90, 140-1, para. 118 (12 July).

102 Sopron-Köszeg Local Railway Company (The Sopron-Köszeg Local Railway Company/ Austria \& Hung.), Award, 1929, II R.I.A.A. 961, 967 (18 June).

103 Dispute between France and the Netherlands in regard to the limits of their respective colonies in Guyana, Award, 1891, XXVIII R.I.A.A. 249, at 253 (25 May). 
answer of a legal system that makes the peaceful settlement of disputes obligatory, but does not provide compulsory means for reaching such a settlement.

\section{Technicalities in the Settlement of Territorial Disputes}

\section{Legal analysis and the historical character of the facts concerning territorial disputes}

Territorial disputes often involve facts that date from long periods of time, sometimes centuries. In the Western Sahara advisory opinion, the Court clarified that:

The reference in those questions to a historical period cannot be understood to fetter or hamper the Court in the discharge of its judicial functions. That would not be consistent with the Court's judicial character; for in the exercise of its functions it is necessarily called upon to take into account existing rules of international law which are directly connected with the terms of the request and indispensable for the proper interpretation and understanding of its Opinion. ${ }^{104}$

This statement has often been contested by relying on another dictum of the Court in the Minquiers and Ecrehos (France v. United Kingdom) case. In this case, the Court affirmed that:

The view is expressed by the French Government that the dismemberment of the Duchy of Normandy, which in fact occurred in 1204 when Continental Normandy was occupied by the King of France, has legal consequences in the present dispute. It is said that if the United Kingdom Government is unable to establish its claim to the Ecrehos and the Minquiers, the title to these islets must be considered as having remained with France since 1204. But since that time there has been a further development in the territorial position. Many wars and peace settlements between the two States succeeded each other during the following centuries. (...) In such circumstances it is difficult to see why the dismemberment of the Duchy of Normandy in 1204 should have the legal consequences attributed to it by the French Government. What is of decisive importance, in the opinion of the Court, is not indirect presumptions deduced from events in the Middle Ages, but the evidence which relates directly to the possession of the Ecrehos and Minquiers groups. ${ }^{105}$

However, as it is apparent from the excerpt quoted above, the Court was merely dismissing the presumptions upon which France relied in order to substantiate its claims to the Minquiers and Ecrehos. The Court was neither excluding the relevance of historical events in establishing titles of territorial sovereignty nor establishing actual possession as the decisive criterion for settling territorial disputes. Rather, in other cases, the Court itself relied upon historical materials in order to justify its decision on the sovereignty over the disputed territory, sometimes from centuries ago. ${ }^{106}$ Still, the fact that the settlement of a territorial dispute might involve historical facts and

\footnotetext{
104 Western Sahara, Advisory Opinion, 1975 I.C.J. 12, at 30 para. 52 (16 October) [emphasis added].

105 Minquiers and Ecrehos (Fr. v. U.K.), Judgment, 1953 I.C.J. 47, 57 (17 November) [emphasis added].

106 See Legal Status of Eastern Greenland (Den. v. Nor.), Judgment, 1933 P.C.I.J. (ser. A/B) No. 53, at 27 (5 April).
} 
different systems of international law requires the identification of technical rules that will allow for the application of the appropriate rules to the case concerned.

\section{The relevance of the critical date and the intertemporal law}

Chapter 10 of this book addresses two technical rules of international law that serve to tackle the impact of the time factor in territorial disputes, that is to say, the intertemporal law and the critical date. Technical rules of international law do not deal with the substance of the territorial claims that are brought before international tribunals and courts. The main characteristic of these rules resides in the fact that they allow the performance of a legal task, in our case, the assessment of the validity of territorial claims. As such, these rules are relevant for any actor, a judge, a student, or a legal adviser engaging in this task. Although technical rules of international law are inherent to any law application process, they find in the realm of territorial disputes a privileged arena. The importance of the critical date resides in the determination of the moment in which the parties have advanced their claims and the dispute arose. Logically speaking, their respective claims must now be assessed. Its impact in the determination of the facts legally relevant in deciding a territorial dispute is apparent. The critical date serves to 'distinguish (...) between those acts which should be taken into consideration for the purpose of establishing or ascertaining sovereignty and those acts occurring after such date' ${ }^{107}$

As far as the intertemporal law is concerned, it relates to the determination of the law applicable to solve the dispute. As will be seen, it contains two rules: according to the first one, a fact or situation must be legally assessed based on the law in force at the time it was produced. The second rule requires that the maintenance of a right must respect the evolution of the law. Thus, the intertemporal law rules tackle the problem of the validity and continuing validity of rights acquired in different systems of international law. Three examples can be found in territorial disputes. The acquisition of territory by force is an area of the law where the international law framework has witnessed a change of rules throughout time. Whereas until the nineteenth century it was possible to acquire territorial sovereignty through a lawful use of force, the international legal order arising from the UN Charter prohibits the use of force altogether, including the use of force as a means of acquisition of territorial sovereignty. The question logically arises whether the new rule of international law prohibiting the acquisition of territorial sovereignty by force invalidates titles of territorial sovereignty acquired at a moment when conquest was allowed. The answer is negative. The second example concerned the acquisition of sovereignty during colonial expansion. Again, the question arises whether legal rights, in this case territorial sovereignty or protectorates, acquired during a legal order allowing that acquisition, could survive the contemporary rules of international law prohibiting colonial possessions. Addressing this legal issue, Max Huber considered rules of logic and stated that:

As regards the question which of different legal systems prevailing at successive periods is to be applied in a particular case (the so-called inter-temporal law), a distinction is to be applied

107 Sovereignty over Pedra Branca/Pulau Batu Puteh, Middle Rocks and South Ledge (Malay./Sing), Judgment, 2008 I.C.J. 12, 28 para. 32 (23 May). 


\section{Research handbook on territorial disputes in international law}

between the creation of rights and the existence of rights. The same principle which subjects the act creative of a right to the law in force at the time the right arises, demands that the existence of the right, in other words its continued manifestation, shall follow the conditions required by the evolution of law. ${ }^{108}$

It would, of course, be nonsensical to examine the acquired territorial sovereignty in the sixteenth century using rules that have developed only in the later twentieth century. Logic, often phrased as the principle of contemporaneity aspect of the intertemporal law rule, dictates that in order to determine whether a state acquired territorial sovereignty in the sixteenth century, the rules applicable at that time are applied. To answer the first question referred to above, the validity of conquest as a means of acquiring territorial sovereignty in the nineteenth century has to be assessed in the light of the system of international law applicable in the eighteenth century. Similarly, it would not make any sense to determine whether titles of territorial sovereignty acquired in the sixteenth century are still valid in the contemporary legal order, using the sixteenth century legal order as the framework of analysis. As apparent, the question itself dictates the relevant legal order for legal analysis. The contemporary maintenance of territorial sovereignty acquired in the sixteenth century has to be determined in light of the rules of international law valid nowadays.

The third example concerns some claims relating to what was called the doctrine of the reversion of sovereignty under international law. According to this doctrine, newly independent states could claim the territorial sovereignty of entities that existed before the imposition of colonialism. These claims, which were advanced by Pakistan in the Rann of Kutch case, Libya in its dispute with Chad and Yemen in its dispute with Eritrea, were dismissed by the arbitral tribunals or the International Court of Justice. ${ }^{109}$ Here both principles of the intertemporal law come into play. By virtue of the first principle, the loss of sovereignty by the local entities must be assessed taking into account the law in force at the time of the imposition of the colonial rule. By the second, it is not possible to apply the contemporary principle of self-determination retrospectively.

\section{Evidence in territorial disputes}

Proof of title is crucial in territorial disputes. This is developed in Chapter 12 of this Research Handbook. Although falling under technical rules of international law, not all evidentiary matters are governed by procedural rules. Some evidentiary matters are regulated by, or dependent on, substantive rules, whereas others draw on logic. International courts and tribunals, as well as the parties to the disputes submitted to them, enjoy a large freedom with regard to the means of production of evidence. Evidentiary matters governed by substantive rules of international law stem from different sources depending on what is to be proven.

\footnotetext{
108 Island of Palmas/Miangas (Neth./U.S.), Award, 1928, II R.I.A.A. 829, at 846 (4 April).

109 Indo-Pakistan Western Boundary (Rann of Kutch) (India/Pak.), Award, 1968, XVII R.I.A.A. 1, at 528 (19 February); Territorial Dispute (Libya v. Chad), Judgment, 1991 I.C.J. 94, 1, 38, para. 75 (26 August); Territorial Sovereignty and Scope of the Dispute (Eri./Yemen), Award (First Phase of Proceedings), 1998, XXII R.I.A.A. 209, at 243, para. 125 (9 October).
} 
As far as territorial sovereignty is concerned, evidentiary matters are subordinate to the relation titles-effectivités. As a consequence, evidence proving a title of territorial sovereignty prevails over the mere evidence of effectivités, that is to say, sovereign acts performed in a disputed territory. However, evidentiary matters also follow a subtler nuance. The majority of titles of territorial sovereignty over a territory are based on consent and not merely on the effectivités that the parties performed in the disputed territory. What generally remains crucial in territorial disputes is the demonstration that one side accepted in some way the existence and validity of the claim invoked by the other. Therefore, except in cases when both parties fail to prove the existence of a title of territorial sovereignty, cases are not won or lost by the mere weight of the evidence of effectivités accomplished in a given territory. ${ }^{110}$ In other words, evidence should focus on establishing the perception of the parties with respect to the title sovereignty over the disputed territory.

As far as the standards of review of evidence are concerned, they also depend on whether the judge or arbitrator establishes whether there is a title or not. The first standard that the international tribunals use consists in determining whether one of the parties possesses sovereignty over the disputed territory in accordance with the rules of international law. As shown in Chapter 4, only when the judge or arbitrator fails to establish the existence or scope of title does he or she engage in the balancing of the effectivités adduced by the parties to the dispute. As Max Huber explained in the Palmas/Miangas Island (Netherlands/USA) case, as a right, sovereignty hardly belongs to two parties at the same time, except in a few historical cases such as condominium. ${ }^{11}$ In this regard, it is important to distinguish claims to territorial sovereignty from titles of territorial sovereignty. ${ }^{112}$ A tribunal or court, which is seized to decide a territorial dispute, will certainly have to evaluate the respective claims of the parties. However, such a task is not a balancing of different titles of sovereignty, except if one confuses claims to territorial sovereignty and titles thereof. ${ }^{113}$ In other words, a tribunal is not deciding which title is the strongest between two competing titles. Consequently, the first task ascribed to a tribunal in a territorial dispute consists in identifying the party to the dispute that holds the relevant title of territorial sovereignty.

Concerning the burden of proof, territorial disputes borrow from the general principle of procedure that it is for the party who makes a claim to prove it. ${ }^{14}$ Both

110 Croatia/Slovenia Arbitration, Award, 2017, 1, at 110, para. 342 (Perm. Ct. Arb, 29 June) (observing that '[e]valuation of effectivités is not a matter of counting or comparing instances of the exercise or display of authority à titre de souverain. Each instance - and the number of relevant instances put before an international tribunal in cases such as this tends to be low must be examined in order to identify precisely what can properly be inferred from it.').

111 Island of Palmas/Miangas (Neth./U.S.), Award, 1982, II R.I.A.A. 829, at 838 (4 April).

112 See the fitting statement of the World Trade Organization Appellate Body Report, United States - Measure Affecting Imports of Woven Wool Shirts and Blouses from India, 14, WTO Doc. WT/DS33/AB/R 1 (adopted 25 April, 1997): '[W]e find it difficult, indeed, to see how any system of judicial settlement could work if it incorporated the proposition that the mere assertion of a claim might amount to proof.'

113 Legal Status of Eastern Greenland (Den. v. Nor.), Judgment 1933 P.C.I.J. (ser. A/B) No. 53, at 46 (5 April).

114 Temple of Preah Vihear (Cambodia v. Thai.), Merits, 1962 I.C.J. 6 (15 June). 


\section{Research handbook on territorial disputes in international law}

parties in a territorial dispute have to prove their respective claims. However, from the moment a state has successfully established the validity of its claim to a territory, the burden falls on the other state to prove that such a title has been transferred to it either expressly through a treaty or tacitly through acquiescence. Acquiescence, however, is not presumed lightly because of the "central importance in international law and relations of State sovereignty over territory and of the stability and certainty of that sovereignty'. To the contrary,

[a]ny passing of sovereignty over territory on the basis of the conduct of the Parties, as set out above, must be manifested clearly and without any doubt by that conduct and the relevant facts. That is especially so if what may be involved, in the case of one of the Parties, is in effect the abandonment of sovereignty over part of its territory. ${ }^{115}$

As this overview revealed, territorial disputes are a field of international law where various rules play at different stages of the procedure. The different chapters in this Research Handbook map the main concepts, rules and techniques structuring the field.

115 Sovereignty over Pedra Branca/Pulau Batu Puteh, Middle Rocks and South Ledge (Malay./Sing), Judgment, 2008 I.C.J. 12, 51 paras. 122 (23 May). 